OPEN ACCESS

Edited by:

Barbara Rolfe,

University of Queensland, Australia

Reviewed by:

Cristian Smerdou,

University of Navarra, Spain

Connie Jackaman,

Curtin University, Australia

*Correspondence:

You-Wen $\mathrm{He}$

youwen.he@duke.edu

Specialty section:

This article was submitted to

Cancer Immunity and Immunotherapy,

a section of the journal

Frontiers in Immunology

Received: 29 November 2018

Accepted: 24 June 2019

Published: 19 July 2019

Citation:

Wang Y, Zhang H and He Y-W (2019)

The Complement Receptors C3aR

and C5aR Are a New Class of

Immune Checkpoint Receptor in

Cancer Immunotherapy.

Front. Immunol. 10:1574

doi: 10.3389/fimmu.2019.01574

\section{The Complement Receptors C3aR and C5aR Are a New Class of Immune Checkpoint Receptor in Cancer Immunotherapy}

\author{
Yu Wang ${ }^{1}$, Hui Zhang ${ }^{2}$ and You-Wen $\mathrm{He}^{3 *}$ \\ ${ }^{1}$ Life Science Institute, Jinzhou Medical University, Jinzhou, China, ${ }^{2}$ First Affiliated Hospital, China Medical University, \\ Shenyang, China, ${ }^{3}$ Department of Immunology, Duke University Medical Center, Durham, NC, United States
}

Cancer immunotherapy has made remarkable clinical advances in recent years. Antibodies targeting the immune checkpoint receptors PD-1 and CTLA-4 and adoptive cell therapy (ACT) based on ex vivo expanded peripheral CTLs, tumor infiltrating lymphocytes (TILS), gene-engineered TCR- and chimeric antigen receptor (CAR)-T cells have all shown durable clinical efficacies in multiple types of cancers. However, these immunotherapeutic approaches only benefit a small fraction of cancer patients as various immune resistance mechanisms and limitations make their effective use a challenge in the majority of cancer patients. For example, adaptive resistance to therapeutic PD-1 blockade is associated with an upregulation of some additional immune checkpoint receptors. The efficacy of transferred tumor-specific $T$ cells under the current clinical ACT protocol is often limited by their inefficient engraftment, poor persistence, and weak capability to attack tumor cells. Recent studies demonstrate that the complement receptor C3aR and C5aR function as a new class of immune checkpoint receptors. Complement signaling through $\mathrm{C} 3 \mathrm{aR}$ and $\mathrm{C} 5 \mathrm{aR}$ expressed on effector $\mathrm{T}$ lymphocytes prevent the production of the cytokine interleukin-10 (IL-10). Removing $\mathrm{C} 3 a \mathrm{R} / \mathrm{C} 5 \mathrm{aR}-\mathrm{mediated}$ transcriptional suppression of $\mathrm{IL}-10$ expression results in endogenous IL-10 production by antitumor effector $\mathrm{T}$ cells, which drives $\mathrm{T}$ cell expansion and enhances $T$ cell-mediated antitumor immunity. Importantly, preclinical, and clinical data suggest that a signaling axis consisting of complement/C3aR/C5aR/IL-10 critically regulates $T$ cell mediated antitumor immunity and manipulation of the pathway ex vivo and in vivo is an effective strategy for cancer immunotherapy. Furthermore, a combination of treatment strategies targeting the complement/C3aR/C5aR/IL-10 pathway with other treatment modalities may improve cancer therapeutic efficacy.

Keywords: complement, cancer immuno therapy, complement receptor C3aR, complement receptor C5aR, IL-10 (interleukin-10), PD-1 - PDL-1 axis, immune check point

\section{INTRODUCTION}

As a major component of the innate immunity, the complement system also directly regulates lymphocyte function $(1,2)$. Recent studies have shed important insights to the role of complement and its receptors in antitumor immunity. Clinical observations and animal studies suggest that complement signaling inhibits antitumor immunity. It was reported that tumor or circulating 
complement levels are positively correlated with tumor size and poor outcome in different types of cancers, such as neuroblastoma, colorectal, lung, ovarian cancer, chronic lymphocytic leukemia, and carcinomas of the digestive tract (3). Extensive animal studies have also demonstrated that the complement system functions to inhibit antitumor immunity (4-15). Mechanistically, complement may inhibit antitumor immunity by promoting recruitment of myeloid-derived suppressor cells (MDSCs) into the tumor microenvironment (TME) $(4-6,9,12,13)$ or by suppressing dendritic cells (DCs)/NK cell activation $(7,8)$. Recent studies suggest that a new mechanism plays an important role in complement signaling-mediated suppression of antitumor immunity: direct inhibition of IL-10 production in $\mathrm{CD}^{+}$tumor infiltrating lymphocytes (TILs) in TME $(11,14)$. Here, we summarize relevant findings and propose that $\mathrm{C} 3 \mathrm{aR}$ and $\mathrm{C} 5 \mathrm{aR}$ function as a new class of immune checkpoint receptors that should be targeted for cancer immunotherapy.

\section{COMPLEMENT SUPPRESSES ANTITUMOR IMMUNITY THROUGH C3aR AND C5aR}

In addition to the many clinical reports positively correlating complement levels with tumor size and poor outcome in various human cancers [reviewed by Pio et al. (3)], animal studies testing different tumor types in different mouse models also show that the complement signaling pathway exerts potent inhibition on antitumor immunity (4-15) (Table 1). The tested mouse tumor models include TC-1 cervical cancer, Lewis lung cancer, RMA lymphoma, 4T1, and E0771 breast cancer, B16 melanoma, HPV16 skin cancer, and MC38 colon cancer with either transplanted tumor cells or spontaneously developed cancers. Complement signaling was disrupted in these animal studies by using genetic models including mice deficient for C3, C4, C3aR, or C5aR1 $(4,9-15)$ or inhibitors to complement C3, C3aR, and C5aR1 $(4-6,8,10-12,14)$. The reported results are highly consistent in that tumor growth is suppressed when complement-mediated signaling is inhibited or removed. In studying the underlying cellular mechanisms, Markiewski and colleagues first showed that $\mathrm{C} 5 \mathrm{a} / \mathrm{C} 5 \mathrm{aR} 1$ interaction promotes the migration of MDSCs into tumors and enhances the suppressive capacity of tumor-associated MDSCs (4). The regulation of myeloid suppressor cells in tumors by complement signaling is also observed by several other studies $(5,6,9,12,13)$. Thus, a major immune suppressive role by complement signaling may be mediated through recruitment of MDSCs into tumors. In addition to MDSCs, other innate cell populations such as neutrophils, DCs and NK cells are also involved in complementmediated immune suppression of antitumor immunity $(7,8,10)$. When complement C3 is exhausted using cobra venom factor, NK cells are greatly increased in tumors and depletion of NK cells nullifies the enhanced antitumor activity induced by cobra venom factor treatment (8). Although complement signaling modulates innate immune cell activities, the enhanced antitumor immunity exhibited in mice following disruption of complement signaling is T lymphocyte dependent. Not only effector CD4 ${ }^{+}$ and $\mathrm{CD}^{+}$TILs are enhanced in these mice but also depletion of T cells through TCR $\alpha$ genetic deletion or antibodies against $\mathrm{CD}^{+}$or $\mathrm{CD}^{+} \mathrm{T}$ cells diminishes the enhanced antitumor immunity in the complement signaling deficient models $(4,8-$ 15). These studies suggest that multiple immune suppressive mechanisms are induced by $\mathrm{C} 3 \mathrm{aR}$ and $\mathrm{C} 5 \mathrm{aR} 1$ signaling (Table 1).

\section{C3aR AND C5aR-MEDIATED IMMUNE SUPPRESSION ON T LYMPHOCYTES}

Three small cationic peptides, C3a, C4a, and C5a, generated by complement activation are termed as anaphylatoxins. These peptides induce chemotaxis, cell activation, and inflammatory signaling by binding to their respective G-protein-coupled receptors (GPCR), referred to as C3aR and C5aR1. The models for anaphylatoxins binding to their cognitive receptors have been proposed after the molecular cloning of C3aR and C5aR1 (19). In the immune system, $\mathrm{C} 3 \mathrm{aR}$ is predominantly distributed on leukocytes of myeloid lineages, such as neutrophils, basophils, eosinophils, mast cells, monocytes/macrophages (20-23). Ligand-receptor engagement induced receptor phosphorylation leads to receptor desensitization, internalization, and activation of diverse downstream signaling pathways in different cell types. $\mathrm{C} 3 \mathrm{aR}$ is highly expressed on neutrophils, and $\mathrm{C} 3 \mathrm{a}$ induces calcium influx in response to C3a (24); however, C3aR inhibits neutrophil mobilization in vivo in an intestinal ischemiareperfusion model (25). In mast cells, C3a activates PI3K signaling pathways and subsequent Akt-phosphorylation, as well as MAP kinases Erk1/Erk2 to promote cytokine expression (26). In human monocyte/macrophage, engagement of C3a to Ca3R, together with TLR signaling induces secretion of proinflammatory cytokines such as IL- $1 \beta$, IL-6, and TNF $\alpha$ $(27,28)$. C3aR signaling modulates IL-1 $\beta$ secretion through NLRP3 inflammasome activation by regulating ATP efflux (29). Similar to C3aR, C5aR is abundantly expressed in neutrophils, eosinophils and basophils, monocytes/macrophages, and mast cells (30-33). C5a binding to C5aR causes calcium flux as well as activation of several components of different signaling pathways, including PI3K- $\gamma$ kinase, phospholipase C, phospholipase D and Raf-1/B-Raf mediated activation of MEK-1 (34-37). In addition to a similar proinflammatory function of $\mathrm{C} 3 \mathrm{aR}, \mathrm{C} 5 \mathrm{aR} 1$ is also a chemotactic receptor. Upon engagement with C5aR1, C5a serves as a chemoattractant for monocytes, neutrophils, eosinophils, and basophils (38).

It is well established that complement components and their receptors $\mathrm{C} 3 \mathrm{aR}$ and $\mathrm{C} 5 \mathrm{aR} 1$ are expressed in not only myeloid and tumor cells but also CD4 ${ }^{+}$T lymphocytes (39-44). Furthermore, endogenously or locally produced $\mathrm{C} 3 \mathrm{a}$ and $\mathrm{C} 5 \mathrm{a}$ bind to $\mathrm{C} 3 \mathrm{aR}$ and $\mathrm{C} 5 \mathrm{aR}$ on $\mathrm{CD} 4^{+} \mathrm{T}$ cells and regulate $\mathrm{T}$ cell function, such as differentiation, survival and cytokine production (40, 41, 45, 46). Interestingly, in contrast to the lack of C3aR and C5aR1 expression on peripheral $\mathrm{CD}^{+} \mathrm{T}$ cells in naive mice, both receptors are strongly upregulated on $\mathrm{CD}^{+}$TILs from mouse and human tumors (11). Overall, $\sim 20 \%$ of $\mathrm{CD}^{+}$TILs are $\mathrm{C} 3 \mathrm{aR}$ and $\mathrm{C} 5 \mathrm{aR}$ double positive. To determine the source of complement that mediates immune suppression on $\mathrm{CD} 8^{+} \mathrm{TILs}$, 
TABLE 1 | Mouse models on the complement/C3aR/C5aR1/IL-10 pathway in antitumor immunity.

\begin{tabular}{|c|c|c|c|}
\hline Reference & Animal strain/Treatment & Tumor type & Phenotype \\
\hline Ajona et al. (12) & PD-1/C5a double blockade & Lung cancer & Growth and metastasis inhibition \\
\hline Cho et al. (16) & $\mathrm{C} 3^{-/-}$mice, C5a silencing in tumor & Ovarian cancer & C5a recruits MDSCs to tumor microenvironment \\
\hline Corrales et al. (5) & C5aR antagonist & Lung cancer & C5a recruits MDSCs to tumor microenvironment \\
\hline Emmerich et al. (17) & $\mathrm{IL}_{10 R b^{-/}}$mice, IL-10 treatment & Squamous carcinoma & $\mathrm{IL}_{-10}$ promotes anti-tumor $\mathrm{CD}^{+} \mathrm{T}$ cell response \\
\hline Gunn et al. (6) & SCID mice, C5a overexpression & Lymphoma/ovarian cancer & C5a recruits MDSCs \\
\hline Janelle et al. (8) & cobra venom factor treatment & Melanoma & Complement inhibits NK function \\
\hline Kwak et al. (14) & $\mathrm{C}^{-/-}$mice,C3aR, C5aR antagonists & lung Cancer & Complement inhibits CD4 ${ }^{+} \mathrm{T}$ cell function \\
\hline Markiewski et al. (4) & $\mathrm{C} 3^{-/-}, \mathrm{C}^{-/-}$, factor $\mathrm{B}^{-/-}, \mathrm{C} 5 \mathrm{aR}-1-$ mice & Cervical cancer & Complement recruits MDSCs to tumor \\
\hline Medler et al. (15) & K14-HPV16 Tg, ${ }^{-1} 3^{-}$mice & Squamous cell carcinoma & $\mathrm{C5a/C5aR}$ regulate macrophage/mast cell \\
\hline Mumm et al. (18) & IL-10-/-, IFNg ${ }^{-/-}$, MMTV-rtHer2 Tg mice & Squamous tumor/thymoma & IL-10 promotes $\mathrm{CD}^{+}+\mathrm{T}$ cell function \\
\hline Nabizadeh et al. (10) & ${\mathrm{C} 3 a R^{-/}-\text {mice, }} \mathrm{C} 3 \mathrm{aR} / \mathrm{C} 5 \mathrm{aR}$ antagonists & melanoma, colon, breast cancer & Complement inhibits $\mathrm{CD}^{+}{ }^{+} \mathrm{T}$ cell and neutrophil \\
\hline Qing et al. (7) & $\mathrm{C} 3^{-/-}$and $\mathrm{C} 5 \mathrm{aR}^{-/-}$mice & Melanoma & Complement inhibits DC-NK function through MDSCs \\
\hline Vadrevu et al. (9) & $\mathrm{C} 5 \mathrm{aR}^{-/-}$mice, C5aR antagonist & Breast cancer & Complement inhibits T cell through Treg and MDSCs \\
\hline Wang et al. (11) & $\begin{array}{l}\mathrm{C} 3^{-/-}, \mathrm{IL}-10^{-/-}, \mathrm{TCR}^{-/-} \text {mice, } \mathrm{C} 3 \mathrm{aR} \text { and } \\
\text { C5aR antagonists }\end{array}$ & Melanoma/colon/breast cancer & Complement inhibits antitumor CD8 ${ }^{+} \mathrm{T}$ cell by \\
\hline Zha et al. (13) & $\begin{array}{l}\mathrm{C} \mathrm{aR}^{-/-} \text {mice, } \mathrm{PD}-1 \text { blockade and C5aR } \\
\text { antagonist }\end{array}$ & Melanoma/colon cancer & C5a/PD-1 blockade enhances antitumor efficacy \\
\hline
\end{tabular}

chimeric mice with either lymphocytes or host cells lacking $\mathrm{C} 3$ were used as tumor-bearing hosts. C3-deletion in $\mathrm{CD}^{+} \mathrm{T}$ cells was sufficient to remove complement-mediated suppression on antitumor immunity (11), suggesting that autocrine C3 production and the interaction of activation products with $\mathrm{Ca} 3 \mathrm{R} / \mathrm{C} 5 \mathrm{aR}$ plays a critical role in suppressing effector $\mathrm{CD}^{+}$ TIL function.

\section{C3aR AND C5aR SIGNALING INHIBITS IL-10 PRODUCTION IN TUMOR INFILTRATING T LYMPHOCYTES}

How does autocrine complement signaling inhibit effector CD8 ${ }^{+}$ $\mathrm{T}$ cell function? Several clues suggest a possible mechanism underlying $\mathrm{C} 3 \mathrm{aR} / \mathrm{C} 5 \mathrm{aR}$ signaling-mediated immune checkpoint function: complement signaling may inhibit IL-10 production in effector $\mathrm{T}$ lymphocytes given the role of $\mathrm{IL}-10$ in $\mathrm{CD}^{+}$ TIL expansion and immune activating function in antitumor immunity (see Discussion in next section). First, it was shown that a fraction of $\mathrm{CD}^{+}$effectors expresses IL-10 at the peak of coronavirus infection and the $\mathrm{IL}-10^{+} \mathrm{CD} 8^{+} \mathrm{T}$ cells show superior CTL activity and in vivo protection against chronic infection (47). Second, we found that complement pathway related genes are enriched in the $\mathrm{IL}-10^{+} \mathrm{CD} 8^{+} \mathrm{T}$ cells (11), suggesting a possibility of mutual or reciprocal regulation. Indeed, in $\mathrm{C}^{-/-}$Il10 reporter (Tiger) mice, $\mathrm{CD} 8^{+}$TILs within B16 tumors but not peripheral blood readily express IL-10 (11). Kwak and colleagues also observed enhanced IL-10 expression in $\mathrm{CD}^{+}$and $\mathrm{CD}^{+}{ }^{+} \mathrm{T}$ lymphocytes in lungs of tumor-bearing C3-deficient mice (14). Furthermore, antagonists to C3aR and C5aR1 also promote IL-10 production in $\mathrm{CD}^{+}$TILs as well as in vitro activated $\mathrm{CD} 8^{+} \mathrm{T}$ cells (11). Importantly, the enhanced antitumor immunity in complement-deficient mice or wildtype mice treated with antagonists to $\mathrm{C} 3 \mathrm{aR}$ and $\mathrm{C} 5 \mathrm{aR} 1$ depend on IL-10. Depletion of the IL-10 gene in these mice completely abolishes the enhanced antitumor immunity in both melanoma and breast cancer tumor-bearing C3-deficient mice (11). The suppression of IL-10 production in $\mathrm{CD}^{+}$TILs is mediated through endogenously produced complement and its autocrine interaction with $\mathrm{C} 3 \mathrm{aR}$ and $\mathrm{C} 5 \mathrm{aR}$ on $\mathrm{CD} 8^{+} \mathrm{T}$ cells. The inhibition on IL-10 production by signaling through $\mathrm{C} 3 \mathrm{aR}$ and $\mathrm{C} 5 \mathrm{aR}$ is redundant as antagonism to one of these receptors alone does not promote IL-10 production. Accordingly, antagonism to $\mathrm{C} 3 \mathrm{aR}$ and $\mathrm{C} 5 \mathrm{aR} 1$, but not to a single receptor, suppresses tumor growth and the antitumor effect depends on IL-10 in vivo (11). Therefore, inhibition of antitumor immunity through suppression of IL-10 production in $\mathrm{CD}^{+}$TILs in response to complement/C3aR/C5aR signaling represents a new mechanism of complement-mediated immune supression (48).

\section{IL-10 FUNCTIONS AS AN IMMUNE ACTIVATING CYTOKINE IN CANCER IMMUNOTHERAPY}

IL-10 is a pleiotropic cytokine produced by many cell populations, including but not limited to activated $\mathrm{T}$ cells, B cells, macrophages as well as mast cells $(49,50)$. Although it was initially identified as a cofactor for thymocytes growth and $\mathrm{T}$ cell activation, IL-10 was further recognized as a regulatory cytokine due to its anti-inflammatory functions. IL-10 impairs the maturation of dendritic cells and macrophages by interfering with upregulation of costimulatory molecules such as CD80, CD86, MHCII, and CD83 on activated dendritic cells and macrophages $(51,52)$. In addition, IL-10 skews the Th1/Th2 balance to Th2 by selectively blocking IL-12 synthesis in activated dendritic cells (53). Macrophages can be polarized 
to M1 (inflammatory) or M2 (anti-inflammatory) phenotypes depending on the microenvironmental stimuli. IL-10 inhibits the activation and proliferation through Stat3-dependent and independent pathways and polarizes macrophage to a M2 like phenotype $(54,55)$. IL-10 directly acts on $\mathrm{CD}^{+} \mathrm{T}$ cells to differentiate $\mathrm{T}$ helper cells into inducible regulatory $\mathrm{T}$ cells and maintain the expression of key transcription factor Foxp3 (56, 57). Regulatory $\mathrm{T}$ cells also express IL-10 and mice deficient for IL-10 in regulatory $\mathrm{T}$ cells did not display systemic autoimmunity; however, these mice developed spontaneous colitis, skin and lung hyperreactivity, suggesting an organ specific role of IL-10 on regulatory T cells (58).

Although IL-10 is often associated with an immune suppressive function, recent clinical studies have unequivocally shown that IL-10 is an immune activating cytokine promoting antitumor immunity (59-61). In a phase I clinical trial, pegylated recombinant human IL-10 (rhIL-10) has shown encouraging clinical efficacy in several types of solid tumors (59). Among the 24 patients treated with rhIL-10 monotherapy at 20-40 $\mu \mathrm{g} / \mathrm{kg}$ active dose, the overall objective response rate is $21 \%$. Furthermore, IL-10 treatment increases serum levels of proinflammatory cytokines IL-18 and IFN $\gamma$ as well as FasL in cancer patients and the induced cytokine levels are strongly correlated with clinical responses $(59,61)$. Pegylated rhIL10 treatment dramatically expands $\mathrm{PD}-1^{+} \mathrm{LAG}-3^{+}$activated $\mathrm{CD}^{+} \mathrm{T}$ cells in the blood of cancer patients. Importantly, both the number and effector function of $\mathrm{CD} 8^{+}$TILs from these patients are increased (61). These results support that the major function of rhIL-10 is to expand the number as well as enhance the effector function of antitumor $\mathrm{CD}^{+} \mathrm{T}$ cells

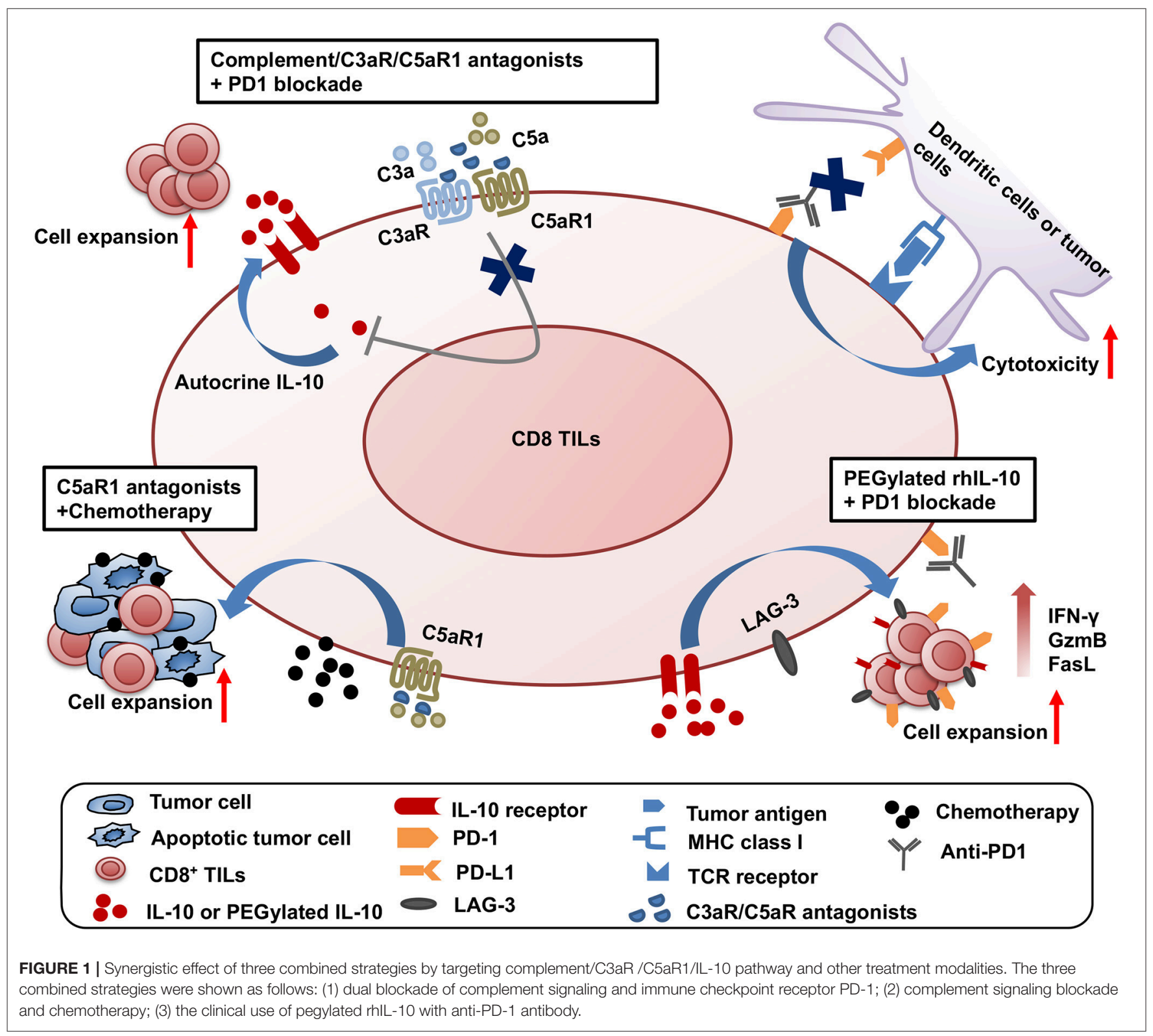


in cancer patients. A Phase 3 clinical trial (NCT02923921) in patients with metastatic pancreatic cancer is being conducted based on promising efficacy data from early clinical studies. Mechanistically, checkpoint inhibition, and IL-10 treatment together enhances the number and quality of pre-existing TILs. The efficacy of PD-1/PD-L1 inhibitors is highly associated with tumor microenvironment such as TIL density, PD-1/PD-L1 expression; tumor intrinsic feature, such as tumor mutational burden, microsatellite instability; as well as gut microbiota (62). The clinical trials of pegylated recombinant human IL10 are focused on several solid tumor types. Its efficacy on solid and blood tumor types needs to be tested clinically in the future.

Another potential application for IL-10 and C3aR/C5aR antagonists is to incorporate them into in vitro expansion protocols of T cells for ACT. IL-2 is the primary cytokine used in the in vitro expansion of TILs and gene-engineered $\mathrm{T}$ cells for clinical use, however, the in vivo efficacy of expanded $\mathrm{T}$ cells under the current clinical ACT protocol is often limited by their inefficient engraftment, poor persistence, and weak capability to attack tumor cells (63-68). It was shown long ago that IL-10 augments IL-2-induced proliferation and promotes CTL activity of activated CD8 ${ }^{+} \mathrm{T}$ cells (69-72). Consistent with animal studies and human clinical trial data showing that IL10 promotes $\mathrm{CD}^{+}$TIL proliferation $(11,17,18,61)$, addition of IL-10 to in vitro culture of TILs from human lung cancer with IL-2 drastically enhances the quantity and quality of the expanded human TILs and upregulates genes related to several signaling pathways, such TCR signaling, Notch signaling, cell cycle and CTL killing (11). Furthermore, pegylated rhIL-10 also prevents continuous TCR-stimulation induced apoptosis of activated human $\mathrm{T}$ cells (61). Interestingly, remissions in lymphoma patients treated with anti-CD19 chimeric antigen receptor (CAR-T) cells are associated with high serum levels of IL-10 and IL-15 (73). These results strongly suggest that the addition of IL-10 to the IL-2-supported in vitro T cell expansion protocol may improve the clinical efficacy of adoptive $\mathrm{T}$ cell therapy. In addition to IL-10, antagonists to C3aR/C5aR1 may also be used in such protocol as the in vitro culture of activated $\mathrm{CD} 8^{+} \mathrm{T}$ cells in the presence of $\mathrm{C} 3 \mathrm{aR} / \mathrm{C} 5 \mathrm{aR} 1$ antagonists induces IL-10 production (11).

\section{SYNERGISTIC EFFECT BY TARGETING COMPLEMENT/C3aR/C5aR/IL-10 PATHWAY AND OTHER TREATMENT MODALITIES}

Significant progress has been made on testing the synergistic effect of combined treatment targeting the complement/C3aR/C5aR/IL-10 pathway and other cancer treatment modalities. The first combined strategy is dual blockade of complement signaling and immune checkpoint receptor PD-1 (Figure 1). The complement signaling/IL-10 pathway is independent of the $\mathrm{PD}-1 / \mathrm{PD}-\mathrm{L} 1$ pathway as modulation of this pathway does not affect the expression of PD-1 on $\mathrm{T}$ cells and PD-L1 on tumor cells (11). Two different experimental systems in which (1) PD-L1-silenced B16F10 tumors were inoculated in C3-deficient mice or (2) B16F10 tumor-bearing wildtype mice were treated with anti-PD1 and antagonists to $\mathrm{C} 3 \mathrm{aR} / \mathrm{C} 5 \mathrm{aR}$ clearly show that blockade of complement signaling and PD-1/PDL1 interaction has dramatic synergistic antitumor effect (11). This synergistic antitumor effect is subsequently confirmed by two other studies $(12,13)$. These data provide important clues to rational design of future clinical trials.

The second combined treatment strategy uses complement signaling blockade and chemotherapy (Figure 1). In a squamous cell carcinoma (SCC) model, antagonist to C5aR1 enhances the treatment efficacy of paclitaxel chemotherapy and the synergistic effect depends on $\mathrm{CD}^{+}$ $\mathrm{T}$ lymphocytes (15). Increased CD8 ${ }^{+}$TILs and the expansion of specific $\mathrm{T}$ cell clones were associated with enhanced efficacy (15).

The third combination is the clinical use of pegylated rhIL-10 with the anti-PD-1 antibody pembrolizumab in a cohort of heavily pretreated patients with melanoma, nosquamous cell lung cancer or renal cell carcinoma (61) (Figure 1). This combination achieved a $42 \%$ objective response rate, in contrast to the $21 \%$ objective response rate by pegylated rhIL-10 monotherapy (59). A combination of pegylated rhIL-10 with anti-PD-1 promotes persistent proliferation and expansion of $\mathrm{LAG}-3^{+} \mathrm{PD}-1^{+} \mathrm{CD}^{+}$ $\mathrm{T}$ cells in the cancer patients. These exciting clinical trial results have opened new avenues for effective cancer immunotherapy.

In summary, we have identified that tumor infiltrating $\mathrm{CD}{ }^{+}$ $\mathrm{T}$ cells express complement receptors $\mathrm{C} 3 \mathrm{aR}$ and $\mathrm{C} 5 \mathrm{aR}$ and complement signaling inhibits anti-tumor functions through repression of endogenous IL-10 production in $\mathrm{CD}^{+}$TILs. We and other groups have also confirmed that endogenous and exogenous IL-10 enhances anti-tumor functions of $\mathrm{CD}^{+} \mathrm{T}$ cells in human and mouse in vitro and in vivo. The independence of complement/C3aR/C5aR/IL-10 from the PD-1/PD-L1 signaling pathway makes it possible to block complement receptors and PD-1/PD-L1 as a combined therapy to treat cancer patients clinically. Results from other groups also suggest that the combined blockade of complement and PD-1/PD-L1 signaling with antibodies improves the efficacy of treatment through other mechanisms. Together, we and other groups provide clear evidences that complement receptors $\mathrm{C} 3 \mathrm{aR}$ and $\mathrm{C} 5 \mathrm{aR}$ are a new class of immune checkpoint receptors.

\section{AUTHOR CONTRIBUTIONS}

YW, HZ, and Y-WH co-wrote the review.

\section{FUNDING}

YW was supported by Innovation Talents Project LR2017019. 


\section{REFERENCES}

1. Carroll MC. The complement system in regulation of adaptive immunity. Nat Immunol. (2004) 5:981-6. doi: 10.1038/ni1113

2. Heeger PS, Kemper C. Novel roles of complement in T effector cell regulation. Immunobiology. (2012) 217:216-24. doi: 10.1016/j.imbio.2011.06.004

3. Pio R, Corrales L, Lambris JD. The role of complement in tumor growth. Adv Exp Med Biol. (2014) 772:229-62. doi: 10.1007/978-1-4614-5915-6_11

4. Markiewski MM, DeAngelis RA, Benencia F, Ricklin-Lichtsteiner SK, Koutoulaki A, Gerard C, et al. Modulation of the antitumor immune response by complement. Nat Immunol. (2008) 9:1225-35. doi: 10.1038/ni.1655

5. Corrales L, Ajona D, Rafail S, Lasarte JJ, Riezu-Boj JI, Lambris JD, et al. Anaphylatoxin C5a creates a favorable microenvironment for lung cancer progression. J Immunol. (2012) 189:4674-83. doi: 10.4049/jimmunol.1201654

6. Gunn L, Ding C, Liu M, Ma Y, Qi C, Cai Y, et al. Opposing roles for complement component $\mathrm{C} 5 \mathrm{a}$ in tumor progression and the tumor microenvironment. J Immunol. (2012) 189:2985-94. doi: 10.4049/jimmunol.1200846

7. Qing X, Koo GC, Salmon JE. Complement regulates conventional DCmediated NK-cell activation by inducing TGF- $\beta 1$ in Gr-1+ myeloid cells. Eur J Immunol. (2012) 42:1723-34. doi: 10.1002/eji.201142290

8. Janelle V, Langlois MP, Tarrab E, Lapierre P, Poliquin L, Lamarre A. Transient complement inhibition promotes a tumor-specific immune response through the implication of natural killer cells. Cancer Immunol Res. (2014) 2:200-6. doi: 10.1158/2326-6066.CIR-13-0173

9. Vadrevu SK, Chintala NK, Sharma SK, Sharma P, Cleveland C, Riediger $\mathrm{L}$, et al. Complement c5a receptor facilitates cancer metastasis by altering T-cell responses in the metastatic niche. Cancer Res. (2014) 74:3454-65. doi: 10.1158/0008-5472.CAN-14-0157

10. Nabizadeh JA, Manthey HD, Steyn FJ, Chen W, Widiapradja A, Md Akhir FN, et al. The complement $\mathrm{C} 3 \mathrm{a}$ receptor contributes to melanoma tumorigenesis by inhibiting neutrophil and CD4+ T cell responses. J Immunol. (2016) 196:4783-92. doi: 10.4049/jimmunol.1600210

11. Wang Y, Sun SN, Liu Q, Yu YY, Guo J, Wang K, et al. Autocrine complement inhibits IL10-dependent T-cell-mediated antitumor immunity to promote tumor progression. Cancer Discov. (2016) 6:1-11. doi: 10.1158/2159-8290.CD-15-1412

12. Ajona D, Ortiz-Espinosa S, Moreno H, Lozano T, Pajares MJ, Agorreta J, et al. A combined PD-1/C5a blockade synergistically protects against lung cancer growth and metastasis. Cancer Discov. (2017) 7:694-703. doi: 10.1158/2159-8290.CD-16-1184

13. Zha H, Han X, Zhu Y, Yang F, Li Y, Li Q, et al. Blocking C5aR signaling promotes the anti-tumor efficacy of PD-1/PD-L1 blockade. Oncoimmunology. (2017) 6:e1349587. doi: 10.1080/2162402X.2017.1349587

14. Kwak JW, Laskowski J, Li HY, McSharry MV, Sippel TR, Bullock BL, et al. Complement activation via a C3a receptor pathway alters CD4(+) $\mathrm{T}$ lymphocytes and mediates lung cancer progression. Cancer Res. (2018) 78:143-56. doi: 10.1158/0008-5472.CAN-17-0240

15. Medler TR, Murugan D, Horton W, Kumar S, Cotechini T, Forsyth AM, et al. Complement $\mathrm{C} 5 \mathrm{a}$ fosters squamous carcinogenesis and limits $\mathrm{T}$ cell response to chemotherapy. Cancer Cell. (2018) 34:e566. doi: 10.1016/j.ccell.2018.09.003

16. Cho MS, Vasquez HG, Rupaimoole R, Pradeep S, Wu S, Zand B, et al. Autocrine effects of tumor-derived complement. Cell Rep. (2014) 6:1085-95. doi: 10.1016/j.celrep.2014.02.014

17. Emmerich J, Mumm JB, Chan IH, LaFace D, Truong H, McClanahan T, et al. IL-10 directly activates and expands tumor-resident CD8(+) T cells without de novo infiltration from secondary lymphoid organs. Cancer Res. (2012) 72:3570-81. doi: 10.1158/0008-5472.CAN-12-0721

18. Mumm JB, Emmerich J, Zhang X, Chan I, Wu L, Mauze S, et al. IL-10 elicits IFN $\gamma$-dependent tumor immune surveillance. Cancer Cell. (2011) 20:781-96. doi: 10.1016/j.ccr.2011.11.003

19. Ember JA, Hugli TE. Complement factors and their receptors. Immunopharmacology. (1997) 38:3-15. doi: 10.1016/S0162-3109(97)0 0088-X

20. Dahinden CA, Bischoff SC, Brunner T, Krieger M, Takafuji S, de Weck AL. Regulation of mediator release by human basophils: importance of the sequence and time of addition in the combined action of different agonists. Int Arch Allergy Appl Immunol. (1991) 94:161-4. doi: 10.1159/000235350
21. Elsner J, Oppermann M, Czech W, Dobos G, Schopf E, Norgauer J, et al. $\mathrm{C} 3 \mathrm{a}$ activates reactive oxygen radical species production and intracellular calcium transients in human eosinophils. Eur J Immunol. (1994) 24:518-22. doi: 10.1002/eji.1830240304

22. Martin U, Bock D, Arseniev L, Tornetta MA, Ames RS, Bautsch W, et al. The human C3a receptor is expressed on neutrophils and monocytes, but not on B or T lymphocytes. J Exp Med. (1997) 186:199-207. doi: 10.1084/jem.186.2.199

23. Zwirner J, Gotze O, Sieber A, Kapp A, Begemann G, Zuberbier T, et al. The human mast cell line HMC-1 binds and responds to C3a but not C3a(desArg). Scand J Immunol. (1998) 47:19-24. doi: 10.1046/j.1365-3083.1998.00250.x

24. Norgauer J, Dobos G, Kownatzki E, Dahinden C, Burger R, Kupper R, et al. Complement fragment $\mathrm{C} 3 \mathrm{a}$ stimulates $\mathrm{Ca} 2+$ influx in neutrophils via a pertussis-toxin-sensitive G protein. Eur J Biochem. (1993) 217:289-94. doi: 10.1111/j.1432-1033.1993.tb18245.x

25. Wu MC, Brennan FH, Lynch JP, Mantovani S, Phipps S, Wetsel RA, et al. The receptor for complement component $\mathrm{C} 3$ a mediates protection from intestinal ischemia-reperfusion injuries by inhibiting neutrophil mobilization. Proc Natl Acad Sci USA. (2013) 110:9439-44. doi: 10.1073/pnas.1218815110

26. Venkatesha RT, Berla Thangam E, Zaidi AK, Ali H. Distinct regulation of C3ainduced MCP-1/CCL2 and RANTES/CCL5 production in human mast cells by extracellular signal regulated kinase and PI3 kinase. Mol Immunol. (2005) 42:581-7. doi: 10.1016/j.molimm.2004.09.009

27. Takabayashi T, Vannier E, Clark BD, Margolis NH, Dinarello CA, Burke JF et al. A new biologic role for C3a and C3a desArg: regulation of TNF-alpha and IL-1 beta synthesis. J Immunol. (1996) 156:3455-60.

28. Fischer WH, Jagels MA, Hugli TE. Regulation of IL-6 synthesis in human peripheral blood mononuclear cells by $\mathrm{C} 3 \mathrm{a}$ and $\mathrm{C} 3 \mathrm{a}$ (desArg). J Immunol. (1999) 162:453-9.

29. Asgari E, Le Friec G, Yamamoto H, Perucha E, Sacks SS, Kohl J, et al. C3a modulates IL-1 $\beta$ secretion in human monocytes by regulating ATP efflux and subsequent NLRP3 inflammasome activation. Blood. (2013) 122:3473-81. doi: 10.1182/blood-2013-05-502229

30. Chenoweth DE, Goodman MG. The C5a receptor of neutrophils and macrophages. Agents Actions Suppl. (1983) 12:252-73. doi: 10.1007/978-3-0348-9352-7_15

31. Gerard NP, Hodges MK, Drazen JM, Weller PF, Gerard C. Characterization of a receptor for $\mathrm{C} 5 \mathrm{a}$ anaphylatoxin on human eosinophils. J Biol Chem. (1989) 264:1760-6.

32. Kretzschmar T, Jeromin A, Gietz C, Bautsch W, Klos A, Kohl J, et al. Chronic myelogenous leukemia-derived basophilic granulocytes express a functional active receptor for the anaphylatoxin C3a. Eur J Immunol. (1993) 23:558-61. doi: 10.1002/eji.1830230239

33. Werfel T, Oppermann M, Begemann G, Gotze O, Zwirner J. C5a receptors are detectable on mast cells in normal human skin and in psoriatic plaques but not in weal and flare reactions or in uticaria pigmentosa by immunohistochemistry. Arch Dermatol Res. (1997) 289:83-6. doi: $10.1007 /$ s004030050159

34. Mullmann TJ, Siegel MI, Egan RW, Billah MM. Complement C5a activation of phospholipase D in human neutrophils. A major route to the production of phosphatidates and diglycerides. J Immunol. (1990) 144:1901-8.

35. Buhl AM, Avdi N, Worthen GS, Johnson GL. Mapping of the C5a receptor signal transduction network in human neutrophils. Proc Natl Acad Sci USA. (1994) 91:9190-4. doi: 10.1073/pnas.91.19.9190

36. Jiang H, Kuang Y, Wu Y, Smrcka A, Simon MI, Wu D. Pertussis toxin-sensitive activation of phospholipase $\mathrm{C}$ by the $\mathrm{C} 5 \mathrm{a}$ and fMet-Leu-Phe receptors. J Biol Chem. (1996) 271:13430-4. doi: 10.1074/jbc.271.23.13430

37. Perianayagam MC, Balakrishnan VS, King AJ, Pereira BJ, Jaber BL. C5a delays apoptosis of human neutrophils by a phosphatidylinositol 3-kinase-signaling pathway. Kidney Int. (2002) 61:456-63. doi: 10.1046/j.1523-1755.2002. 00139.x

38. Springer TA. Traffic signals for lymphocyte recirculation and leukocyte emigration: the multistep paradigm. Cell. (1994) 76:301-14. doi: 10.1016/0092-8674(94)90337-9

39. Werfel T, Kirchhoff K, Wittmann M, Begemann G, Kapp A, Heidenreich F, et al. Activated human T lymphocytes express a functional C3a receptor. $J$ Immunol. (2000) 165:6599-605. doi: 10.4049/jimmunol.165.11.6599

40. Lalli PN, Strainic MG, Yang M, Lin F, Medof ME, Heeger PS. Locally produced $\mathrm{C} 5 \mathrm{a}$ binds to $\mathrm{T}$ cell-expressed $\mathrm{C} 5 \mathrm{aR}$ to enhance effector T-cell 
expansion by limiting antigen-induced apoptosis. Blood. (2008) 112:1759-66. doi: 10.1182/blood-2008-04-151068

41. Strainic MG, Liu J, Huang D, An F, Lalli PN, Muqim N, et al. Locally produced complement fragments $\mathrm{C} 5 \mathrm{a}$ and $\mathrm{C} 3 \mathrm{a}$ provide both costimulatory and survival signals to naive CD4+ T cells. Immunity. (2008) 28:425-35. doi: 10.1016/j.immuni.2008.02.001

42. Kwan WH, van der Touw W, Paz-Artal E, Li MO, Heeger PS. Signaling through $\mathrm{C} 5 \mathrm{a}$ receptor and $\mathrm{C} 3$ a receptor diminishes function of murine natural regulatory T cells. J Exp Med. (2013) 210:257-68. doi: 10.1084/jem.20121525

43. Strainic MG, Shevach EM, An F, Lin F, Medof ME. Absence of signaling into CD4(+) cells via C3aR and C5aR enables autoinductive TGF- $\beta 1$ signaling and induction of Foxp3(+) regulatory T cells. Nat Immunol. (2013) 14:162-71. doi: 10.1038/ni.2499

44. van der Touw W, Cravedi P, Kwan WH, Paz-Artal E, Merad M, Heeger PS. Cutting edge: receptors for $\mathrm{C} 3 \mathrm{a}$ and $\mathrm{C} 5 \mathrm{a}$ modulate stability of alloantigen-reactive induced regulatory T cells. J Immunol. (2013) 190:5921-5. doi: 10.4049/jimmunol.1300847

45. Liszewski MK, Kolev M, Le Friec G, Leung M, Bertram PG, Fara AF, et al. Intracellular complement activation sustains $\mathrm{T}$ cell homeostasis and mediates effector differentiation. Immunity. (2013) 39:1143-57. doi: 10.1016/j.immuni.2013.10.018

46. Arbore G, West EE, Spolski R, Robertson AA, Klos A, Rheinheimer $\mathrm{C}$, et al. $\mathrm{T}$ helper 1 immunity requires complement-driven NLRP3 inflammasome activity in CD4(+) T cells. Science. (2016) 352:aad1210. doi: $10.1126 /$ science.aad1210

47. Trandem K, Zhao J, Fleming E, Perlman S. Highly activated cytotoxic CD8 T cells express protective IL-10 at the peak of coronavirus-induced encephalitis. J Immunol. (2011) 186:3642-52. doi: 10.4049/jimmunol.1003292

48. Peng W, McKenzie JA, Hwu P. Complementing T-cell function: an inhibitory role of the complement system in T-cell-mediated antitumor immunity. Cancer Discov. (2016) 6:953-5. doi: 10.1158/2159-8290.CD-16-0698

49. Ouyang W, Rutz S, Crellin NK, Valdez PA, Hymowitz SG. Regulation and functions of the IL-10 family of cytokines in inflammation and disease. Annu Rev Immunol. (2011) 29:71-109. doi: 10.1146/annurev-immunol-031210-101312

50. Mannino MH, Zhu Z, Xiao H, Bai Q, Wakefield MR, Fang Y. The paradoxical role of IL-10 in immunity and cancer. Cancer Lett. (2015) 367:103-7. doi: 10.1016/j.canlet.2015.07.009

51. McBride JM, Jung T, de Vries JE, Aversa G. IL-10 alters DC function via modulation of cell surface molecules resulting in impaired T-cell responses. Cell Immunol. (2002) 215:162-72. doi: 10.1016/S0008-8749(02)00007-2

52. Mittal SK, Cho KJ, Ishido S, Roche PA. Interleukin 10 (IL-10)-mediated Immunosuppression: MARCH-I INDUCTION REGULATES ANTIGEN PRESENTATION BY MACROPHAGES BUT NOT DENDRITIC CELLS. $J$ Biol Chem. (2015) 290:27158-67. doi: 10.1074/jbc.M115.682708

53. De Smedt T, Van Mechelen M, De Becker G, Urbain J, Leo O, Moser M. Effect of interleukin-10 on dendritic cell maturation and function. Eur J Immunol. (1997) 27:1229-35. doi: 10.1002/eji.1830270526

54. O'Farrell AM, Liu Y, Moore KW, Mui AL. IL-10 inhibits macrophage activation and proliferation by distinct signaling mechanisms: evidence for Stat3-dependent and -independent pathways. EMBO J. (1998) 17:1006-18. doi: 10.1093/emboj/17.4.1006

55. Lopes RL, Borges TJ, Zanin RF, Bonorino C. IL-10 is required for polarization of macrophages to M2-like phenotype by mycobacterial DnaK (heat shock protein 70). Cytokine. (2016) 85:123-9. doi: 10.1016/j.cyto.2016. 06.018

56. Murai M, Turovskaya O, Kim G, Madan R, Karp CL, Cheroutre H, et al. Interleukin 10 acts on regulatory $\mathrm{T}$ cells to maintain expression of the transcription factor Foxp3 and suppressive function in mice with colitis. Nat Immunol. (2009) 10:1178-84. doi: 10.1038/ni.1791

57. Hsu P, Santner-Nanan B, Hu M, Skarratt K, Lee CH, Stormon M, et al. IL-10 potentiates differentiation of human induced regulatory T cells via STAT3 and Foxo1. J Immunol. (2015) 195:3665-74. doi: 10.4049/jimmunol.1402898
58. Rubtsov YP, Rasmussen JP, Chi EY, Fontenot J, Castelli L, $\mathrm{Ye} \mathrm{X}$, et al. Regulatory $\mathrm{T}$ cell-derived interleukin-10 limits inflammation at environmental interfaces. Immunity. (2008) 28:546-58. doi: 10.1016/j.immuni.2008.02.017

59. Naing A, Papadopoulos KP, Autio KA, Ott PA, Patel MR, Wong DJ, et al. Safety, antitumor activity, and immune activation of pegylated recombinant human interleukin-10 (AM0010) in patients with advanced solid tumors. $J$ Clin Oncol. (2016) 290:27158-97. doi: 10.1200/JCO.2016.68.1106

60. Zhang H, Wang Y, Hwang ES, He YW. Interleukin-10: an immuneactivating cytokine in cancer immunotherapy. J Clin Oncol. (2016) 34:3576-8. doi: 10.1200/JCO.2016.69.6435

61. Naing A, Infante JR, Papadopoulos KP, Chan IH, Shen C, Ratti NP, et al. PEGylated IL-10 (Pegilodecakin) induces systemic immune activation, CD8(+) T cell invigoration and polyclonal $\mathrm{T}$ cell expansion in cancer patients. Cancer Cell. (2018) 34:e773. doi: 10.1016/j.ccell.2018.10.007

62. Yi M, Jiao D, Xu H, Liu Q, Zhao W, Han X, et al. Biomarkers for predicting efficacy of PD-1/PD-L1 inhibitors. Mol Cancer. (2018) 17:129. doi: 10.1186/s12943-018-0864-3

63. Feldman SA, Assadipour Y, Kriley I, Goff SL, Rosenberg SA. Adoptive cell therapy-tumor-infiltrating lymphocytes, T-cell receptors, and chimeric antigen receptors. Semin Oncol. (2015) 42:626-39. doi: 10.1053/j.seminoncol.2015.05.005

64. Rosenberg SA, Restifo NP. Adoptive cell transfer as personalized immunotherapy for human cancer. Science. (2015) 348:62-8. doi: 10.1126/science.aaa4967

65. Fesnak AD, June CH, Levine BL. Engineered T cells: the promise and challenges of cancer immunotherapy. Nat Rev Cancer. (2016) 16:566-81. doi: $10.1038 /$ nrc. 2016.97

66. Khalil DN, Smith EL, Brentjens RJ, Wolchok JD. The future of cancer treatment: immunomodulation, CARs and combination immunotherapy. Nat Rev Clin Oncol. (2016) 13:273-90. doi: 10.1038/nrclinonc.2016.25

67. Klebanoff CA, Rosenberg SA, Restifo NP. Prospects for gene-engineered $\mathrm{T}$ cell immunotherapy for solid cancers. Nat Med. (2016) 22:26-36. doi: 10.1038/nm.4015

68. Hammerl D, Rieder D, Martens JWM, Trajanoski Z, Debets R. Adoptive T cell therapy: new avenues leading to safe targets and powerful allies. Trends Immunol. (2018) 39:921-36. doi: 10.1016/j.it.2018.09.004

69. Chen WF, Zlotnik A. IL-10: a novel cytotoxic T cell differentiation factor. J Immunol. (1991) 147:528-34.

70. Yang G, Hellstrom KE, Mizuno MT, Chen L. In vitro priming of tumorreactive cytolytic $\mathrm{T}$ lymphocytes by combining IL-10 with B7-CD28 costimulation. J Immunol. (1995) 155:3897-903.

71. Groux H, Bigler M, de Vries JE, Roncarolo MG. Inhibitory and stimulatory effects of IL-10 on human CD8+ T cells. J Immunol. (1998) 160:3188-93.

72. Santin AD, Hermonat PL, Ravaggi A, Bellone S, Pecorelli S, Roman JJ, et al. Interleukin-10 increases Th1 cytokine production and cytotoxic potential in human papillomavirus-specific CD8(+) cytotoxic T lymphocytes. J Virol. (2000) 74:4729-37. doi: 10.1128/JVI.74.10.4729-4737.2000

73. Kochenderfer JN, Somerville RPT, Lu T, Shi V, Bot A, Rossi J, et al. Lymphoma remissions caused by Anti-CD19 chimeric antigen receptor T cells are associated with high serum interleukin-15 Levels. J Clin Oncol. (2017) 35:1803-13. doi: 10.1200/JCO.2016.71.3024

Conflict of Interest Statement: The authors declare that the research was conducted in the absence of any commercial or financial relationships that could be construed as a potential conflict of interest.

Copyright (c) 2019 Wang, Zhang and He. This is an open-access article distributed under the terms of the Creative Commons Attribution License (CC BY). The use, distribution or reproduction in other forums is permitted, provided the original author(s) and the copyright owner(s) are credited and that the original publication in this journal is cited, in accordance with accepted academic practice. No use, distribution or reproduction is permitted which does not comply with these terms. 